\title{
THE LIMITS OF A LOCKEAN ENVIRONMENTALISM: GOD, HUMAN BEINGS, AND NATURE IN LOCKE'S PHILOSOPHY
}

\author{
LOS LÍMITES DEL MEDIOAMBIENTALISMO DE LOCKE: DIOS, EL SER \\ HUMANO Y LA NATURALEZA EN LA FILOSOFÍA DE LOCKE
}

\author{
Henrik Skaug Sætra \\ Østfold University College. Halden / Noruega \\ henrik.satra@hiof.no \\ https://orcid.org/0000-0002-7558-6451
}

Recibido/Received: 28/10/2019

Modificado/Modified: 04/04/2020

Aceptado/Accepted: 15/06/2020

\begin{abstract}
God gave us the Earth, to use and enjoy. So says the Bible, and so says John Locke (1632-1704). The individualism and liberalism in Locke's philosophy makes it decidedly modern and appealing to us today. However, he often uses God as a source of truth and premises in his arguments. This undermines the modern appearance and leaves us with a philosophy that is at times contradictory, at times brilliant, and at all times fixed to the anthropocentric rail that guides his philosophy. In this article, the element of Locke's philosophy that concerns humanity's relationship with the natural world is examined. Particular attention is paid to the value and nature of both biotic and abiotic nature. I argue that the religious aspects of Locke's philosophy cannot be fully purged in an effort to create a pure rationalist, and this leads me to focus on how the religious aspects relate to Locke's rationalism, and in particular what implications his combination of philosophy and theology carries for the prospects of a Lockean environmentalism. I conclude that such environmentalism has clear limitations, while still providing certain foundations for the idea of sustainability and scientific conservationism.
\end{abstract}

\section{KEYWORDS}

Locke; Environmental ethics; Anthropocentrism; Environmentalism; Christianity.

\section{CONTENTS}

1. Introduction. 2. The natural world, Locke and the Bible. 2.1. Nature - God's gift. 2.2. Christianity and nature. 2.3. Locke the Christian. 2.4. Locke the rationalist. 2.5. The natural world, according to Locke. 2.6. Locke, the rationalist Christian. 3. Locke, environmentalism and environmental ethics. 3.1. Environmentalism. 3.2. Environmental ethics. 3.3. Locke, scientific conservationism and anthropocentrism. 4. Conclusions. References.

\section{RESUMEN}

Dios dio al ser humano la tierra para su uso y disfrute. Así dice la Biblia y así dice John Locke (16321704). El individualismo y el liberalismo en la filosofía de Locke lo hacen sin duda actual y atractivo para nosotros. Sin embargo, Locke utiliza a Dios a menudo como una fuente de verdad y como premisa 
para sus debates y razonamientos. Esto debilita una imagen de modernidad y nos deja con una filosofía que es, en unas ocasiones, contradictoria, en otras, brillante y, en todo momento firme en su línea antropocéntrica que guía su filosofía. En este artículo, se analizan los elementos de la filosofía de Locke que vinculan la relación de la humanidad con el mundo natural. Se presta una atención especial al valor y a la naturaleza, tanto la biótica como la abiótica. Sostengo que los aspectos religiosos de la filosofía de Locke no pueden ser eliminados totalmente en un esfuerzo por crear un racionalista puro, y esto me lleva a focalizar en cómo los aspectos religiosos se relacionan con el racionalismo de Locke y, en particular, qué implicaciones lleva consigo su combinación de filosofía con teología para una perspectiva medioambientalista lockeana. Se concluye afirmando que semejante medioambientalismo tiene claras limitaciones pero sigue aportando determinados fundamentos para la idea de sostenibilidad y conservacionismo científico.

PALABRAS CLAVE

Locke; ética medioambiental; antropocentrismo; medioambientalismo; cristiandad.

\section{SUMARIO}

1. Introducción. 2. El mundo natural, Locke y la Biblia. 2.1. La naturaleza, un regalo de Dios. 2.2. El cristianismo y la naturaleza. 2.3. Locke, el cristiano. 2.4. Locke el racionalista. 2.5. El mundo natural de acuerdo con Locke. 2.6. Locke, el cristiano racionalista. 3. Locke, medioambientalismo y ética medioambiental. 3.1. Medioambientalismo. 3.2. Ética medioambiental. 3.3. Locke, conservacionismo y antropocentrismo científicos. 4. Conclusiones. Bibliografía.

\section{INTRODUCTION}

God gave us the Earth, to use and enjoy. So says the Bible, and so says John Locke (1632-1704). The great grandfather of liberalism is widely read and still influential, and I here examine his position on humanity's place in the grand scheme of things. The individualism and liberalism in Locke's philosophy makes it decidedly modern and appealing to us today. However, he often uses God as a source of truth and premises in his arguments. This undermines the modern appearance and leaves us with a philosophy that is at times contradictory, at times brilliant, and at all times fixed to the anthropocentric rail that guides Locke's philosophy. According to Trachtenberg (2014), both "environmentalists and their opponents" would agree that "no thinker" has had a greater influence on how we treat nature - for better or worse. In particular his theory of property is considered problematic, and Dowling (2001) names Locke and his theory of property one of "three bears" of international environmentalism.

Life, liberty and estate, said John Locke (1632-1704), as he explained that the only proper purpose of the state was the protection of these things. These words, in original and slightly altered forms, sound familiar to most people used to modern liberalism, and so does most of the rest of what John Locke wrote in his famous Two Treatises of Government (1969) in 1689. Contrary to this view of the modern Locke, it is possible to paint a picture of Locke's philosophy as highly influenced by theology. In the first part of this article I analyse the influence of Christianity on Locke's philosophy, and how it shapes Locke's view of the natural world.

In the next part, I examine the possibility of building what I label a "Lockean environmentalism". The basis of this examination is Guha's three main models of environmentalism, which is used as a framework for considering how, if at all, Locke's philosophy is compatible with any of them; the three "generic modes" are by Guha labelled back-to-the-land, scientific conservationism and the wilderness idea (Guha 2014). During 
this process Locke's philosophy will be evaluated in the terms of environmental ethics. What does man's moral community consist of, according to Locke? Who are moral agents, and who are morally considerable/moral patients?

The purpose of this paper is not to paint a picture of Locke as some environmentalist saint or forefather. If anything, what is important is to elucidate the limits of his fundamental philosophy in terms of our relationship to nature. The nature of these limits does not, however, necessarily preclude us from taking care of our habitat, which is why a thorough treatment of the implications of the various choices Locke makes is of importance. While important in and of itself, the paper also clears the ground for a subsequent full treatment of the environmental implications of Locke's liberalism and proto-capitalism. While Locke is often considered as "legitimating proto-capitalist economic expansionism", and thus seen as "anti-green", others have interpreted his philosophy as a foundation of a "reformist liberal environmentalism" (Stephens 2016).

As Wilson (2016) states, Locke is a popular object of environmental political theory criticism, but he also has defenders (Liebell, 2011). The increased attention to the environmental ethics inherent in Locke's philosophy is by Mousie (2019) referred to as the environmental turn in Locke scholarship. In this article I focus on showing that the wide array of various readings of Locke is easily understood when the different aspects of Locke's philosophy are considered. I conclude with a moderate support of the view that Locke can provide limited support for environmentalism in the form of scientific conservationism and a focus on sustainability.

\section{THE NATURAL WORLD, LOCKE AND THE BIBLE}

The natural world is a topic of interest to people living in modern societies. Our environment is of great concern, as we now face a variety of challenges such as land change, climate change, pollution, and reduced biological diversity. Locke, however, lived in a different society, and this article is not an attempt to shoe-horn Locke into modern terminology or to condemn him on the basis of knowledge that modern science has brought forth. It is, however, an attempt to show the limitations of a Lockean approach in a modern world, while also highlighting some of the aspect that $d o$ show promise even in our day and age.

The article is in many respects a sibling to Sætra (2014), where a Hobbesian environmental ethics is examined. The two are natural companions, as they belong to the same political theoretical tradition, while also living in the same country in a period of great intellectual change. Thomas (1991) describes the period from 1500 to 1800 as a period of changing attitudes regarding the relationship between humanity and our environment. While "man's ascendency over the animal and vegetable world" has "been a basic precondition of human history", our definitions of and ideas about this relationship has changed over time. While Hobbes could be seen as a catalyst for the rational examination of this relationship, Locke is a prime example of the tension between rationality and theology, which characterises the period in question (Thomas 1991; Sætra 2014). I refer to Thomas (1991) for more contextual detail, and I focus in what follows mainly on a reading of Locke's own texts without attempting to explain or excuse him on the basis of his time and context.

John Locke - a Christian, a rationalist, or a Christian rationalist? What Locke really was, personally, is of little interest for the present purpose. He presented himself as both things, in varying degrees, and what is important are the implications of the two. Also of importance is 
my choice of focusing on Locke's Christianity, and not Christianity in and of itself.

\subsection{Nature - God's gift}

Locke presents himself as a Christian, or at the very least acknowledges God, Scripture and the major parts of Christianity. While some philosophers manage to mention God without letting him influence their philosophy, Locke gives God an important role, and this is clearly visible in passages such as the following:

God, who hath given the world to men in common, hath also given them reason to make use of it to the best advantage of life and convenience. The earth and all that is therein is given to men for the support and comfort of their being (Locke 1969:134).

This instrumental approach to nature permeates all of Locke's writings, and it is hard not to think that it is influenced by Scripture, especially the famous quote from Genesis, quoted by Locke in Two Treatises, stating that "God blessed them, and God said unto them, be fruitful and multiply, and replenish the earth and subdue it, and have dominion over the fish of the sea, and over the fowl of the air, and over every living thing that moveth upon the earth (Gen. i. 28)" (Locke 1969:22). The translation of this phrase from the original text may be disputed, but that is of less importance for us here, given that it is Locke's opinion and interpretation of it that are examined. He himself uses this English translation, and so it becomes the only interpretation we will pay attention to.

Locke's position on nature is instrumental, in that nature is portrayed as something to be used. Cook (1969:xxvi) says that Locke saw nature as given to people by God, and "[h]e then insists that the gift must have been given for their actual use. God did not give men the earth and its contents simply to contemplate, and contemplating, to perish. They must make use of it, to enjoy the fruits thereof'. That such a view of humanity and nature has important consequences for how we deal with environmental issues seems self-evident; the difference from approaches like Arne Næss' deep ecology, where all life, human or non-human, have intrinsic value and equal rights to flourish, is enormous (Næss 1989:29).

To what extent did God intend for us to make use of this abundant nature around us? When answering this question, Locke brings in his own theory of property and answers: "As much as anyone can make use of to any advantage of life before it spoils, so much he may by his labour fix a property in ..." (Locke 1969:133). God seemingly also agreed with Locke's limitation on the appropriation of property, and nothing one cannot make use of can thus legitimately be appropriated, because "[n]othing was made by God for man to spoil or destroy" (Locke 1969:136). This is the first Lockean proviso of property (Musie 2019).

Locke himself emphasises that God gave nature to all men, not just to a monarch. This was important to him, as he was refuting Robert Filmer's claim that their contemporary kings had a claim to divine power through being descendants of the one first made monarch by God - Adam (Locke 1969:22, 133). Worthy of note is the fact that Locke at times attempts to rationalise his arguments, by claiming that what he says is compliant with both reason and Scripture (Locke 1969:133).

\subsection{Christianity and nature}

White $\operatorname{Jr}$ (1967), in his oft-cited "The historical roots of our ecologic crisis", claims that many of our environmental problems are a direct result of views of nature akin to the ones proclaimed by Locke. He sees this approach to nature as the result of western Christianity ("the most anthropocentric religion the world has seen"), which transformed man from being a part of nature to being an exploiter of nature; Christianity entails a clear duality, where "[m] an and nature are two things, and man is master" (White Jr 1967). 
Meyer (2001) distinguishes between a "dualistic" and "derivative" view of human-nature relations. Whereas the dualistic (humanistic) approach sets humans apart from the rest of nature, a derivative (naturalist) approach consists in seeing humans as part of nature. Locke can hardly avoid the dualistic approach, considering his loyalty to Scripture and the reliance on God, the creator and giver of earth to its human inhabitants.

The value of animals is also central to any understanding of human-nature relations, and Bertrand Russell refers to an illuminating example of how the Pope once refused support for the Society for the Prevention of Cruelty to Animals, since people owe no duty to animals and mistreating them is no sin, due to them not having a soul (Russell 2009:48).

The historians of ideas will have to (continue to) evaluate White's claims, but for our purposes it suffices to state that a humanistic and dualistic approach, such as the one Locke created partly from Christianity, has significant effects on how we think about and treat the natural world. This tradition of thought "not only established a dualism of man and nature but also insisted that it is God's will that man exploit nature for his proper ends" (White Jr 1967).

\subsection{Locke the Christian}

Thus far Locke's view of nature appears to be objectionable from most environmentalist vantage points. However, he does at times propose, for example, that there is injustice involved in the stronger subjugating the weaker, that we should be charitable etc. (Locke 1969:34). One problem with Locke is he very often bases his arguments on God's requirements and commandments. Why is that a problem? These passages become bricks in the Lockean building that is his political philosophy, and for a person who does not accept God as an author of facts, or Locke as his interpreter, these bricks turn into sand, and the whole building crumbles.

An important brick in Locke's construction is his claim that we have no liberty over our own lives. It is important in and of itself, and it is seen throughout his philosophy, and becomes one of the main arguments against absolute monarchy and arbitrary rule: “...it being out of a man's power so to submit himself to another as to give him a liberty to destroy him, God and nature never allowing a man so to abandon himself as to neglect his own preservation; and since he cannot take away his own life, neither can he give another power to take it" (Locke 1969:207). Locke states that a person "has not liberty to destroy himself, or so much as any creature in his possession but where some nobler use than its bare preservation calls for it" - even in the state of liberty (Locke 1969:123).

Reason tells us that we ought not to harm ourselves, says Locke, but reason does not take away our liberty to be unreasonable, does it? There is a deeper cause for this lack of liberty:

...for men being all the workmanship of one omnipotent and infinitely wise Maker

- all the servants of one sovereign master, sent into the world by his order, and about

his business - they are his property whose workmanship they are, made to last during his, not one another's, pleasure ... (Locke 1969:123).

Why do people seek society? At times, Locke argues rationally that it is because the state of nature is too inconvenient, but he also proposes religious arguments. God thought it best for man not to be alone, Locke states, and thus he placed in humans a "strong obligations of necessity, convenience, and inclination to drive [them] into society" (Locke 1969:159). Some of Locke's religious arguments can be considered to be supplementary, or even superfluous, to his core philosophy, but some are integral, such as not having the right to our own lives because God retains it.

Two Treatises is full of Scripture, and "there is a marked ethical and religious dimension 
to the Essay [Concerning Human Understanding]" also (Woolhouse 1997:xi). According to Woolhouse, Locke assumes a "scheme of things", and believes "that we have been put here in this world by a good and wise God" (Woolhouse 1997:xi). While God is present in Locke's philosophy, it is also clearly his ambition to establish that reason is compatible with God's commands; God has given us reason, and Locke wants to show how we should make use of it (Woolhouse 1997:xi).

Divine law is God's law, given by "the light of nature, or the voice of revelation" (Locke 1997:317). Heeding this law is a given for Locke, as God created us and has a right to command us; that God has given us rules to follow, "I think there is nobody so brutish to deny" (Locke 1997:317). These laws are not made explicit, but are referred to as the basic moral rules (Locke 1997:316). Locke may have assumed that these should be found in Scripture, and not in his books on political philosophy. In addition to the law of God, we have positive law ("the law of politic societies") and norms ("the law of fashion, or private censure, are those to which men variously compare their actions"); taken together, these laws form the evaluative basis uses to determine if actions are good or bad (Locke 1997:146, 321). While divine law is not typed out in Locke's works, he often cites Scripture, and states that certain things (like helping one's fellows in need) is God's requirement. Locke seems to attack Hobbes for using self-interest as the "fountain and beginning of this entire law", while he himself finds a "deeper" foundation (Zagorin 2009:100). While Hobbes' laws of nature were spelled out, Locke's natural law as the foundation for morals is less developed (Zagorin 2009:127).

A large part of Locke's philosophy is taken directly from the Bible, and since some of the foundational principles of his philosophy are explicitly defended by arguments of faith, Locke the Christian is clearly an important part of Locke the Philosopher.

\subsection{Locke the rationalist}

Rationalism - here understood as the view that reason can provide answers independently from empirical, religious or emotional grounds - is often used as a description of Locke's political philosophy. We have just seen how this could be somewhat misleading, but let's examine how he got the reputation as a rationalist.

First: what is reason? Reason is quite simply the law that "teaches all mankind who will but consult it that, being all equal and independent, no one ought to harm another in his life, health, liberty, or possessions ..." (Locke 1969:123). God has given us reason "to make use of it to the best advantage of life and convenience", along with the earth and all things on it (and around it) (Locke 1969:134). "Understanding," as related to reason, was put in us by God so that we would be able to enjoy society (which he put in us a desire for) (Locke 1969:159).

What then of the relationship between faith and reason? Woolhouse (1997) suggests that Locke does not place faith before reason, but that they coexist and are both valuable: "revelation has always to answer to reason" and "the moral precepts suggested to us by the Bible can, once suggested, always be authenticated and verified by our reason" (Woolhouse 1997:xxi). This begs the question: if what is revealed can be found out and confirmed through reason, do we really need faith? According to Woolhouse (1997), we kind of do, because Locke places some rather harsh restrictions on our reason, and suggests that reason is in fact something akin to God's instrument for controlling us (Woolhouse 1997:xii).

One of the most important points about reason in Locke's philosophy (if we do not disregard his statements on faith and God and conjure up a pseudo-Locke who is a pure 
rationalist) is that he states that reason is the faculty that distinguishes people from beasts (Locke 1997:590). Some may view a portrayal of Locke as something far removed from a proper rationalist as unfounded, but it seems defensible, given that reason is said to be "natural revelation, whereby the eternal Father of light, and fountain of all knowledge communicates to mankind that portion of truth, which he has laid within the reach of their natural faculties ..." (Locke 1997:616).

There is both a rationalist and a believer in Locke's works. And that, in and of itself, makes it hard to claim that he is a pure rationalist.

\subsection{The natural world, according to Locke}

We saw that Locke claims that reason is the faculty that most clearly separates humans from beasts. But what is Locke's actual philosophy of the natural world? This is where Locke's God really grabs the spotlight, and the consequences for Locke's philosophy aren't necessarily beneficial.

Locke states first that "nature teaches all things" the principle of self-preservation. However, Locke is happy to inform us that God did not leave things with such an unsatisfactory principle (Hobbes and others may disagree), and that he also put in beings a general rule to preserve our young (Locke 1969:44). The care for our young overrules selfpreservation, and this was to Locke an obvious choice, as God wanted his beings to propagate and populate the earth (Locke 1969:44).

We have already seen that God has not provided us with liberty of our own lives, even in the state of nature. Locke's denial of a right to destroy ourselves turns out to be important, since he also denies us a right to destroy "any creature in [our] possession but where some nobler use than its bare preservation calls for it" (Locke 1969:123).

This raises the question: what can be of more value to a life form than preservation? Locke's answer is clear: we can put creatures to uses that are nobler than merely letting them live. An illuminating statement, for sure, but what constitutes "nobility" in this case must be left for another occasion. One would, for example, think that killing an animal just to eat it and stay alive, is not "noble", as we simply choose the preservation of one organism over another. However, if Locke thinks that humans are the noblest creatures, destroying other creatures to promote the "bare preservation" of humans may in fact be thought of as noble.

This is interesting, as it prohibits certain kinds of cruelty and violence towards the animals in our possession. However, as is often the case with the various side remarks made by Locke, they are elsewhere contradicted by other remarks. Just after the aforementioned statement he states that people are equal to such a degree that no one will be allowed to destroy another "as if we were made for one another's uses as the inferior ranks of creatures are for ours" (Locke 1969:123). How could this be interpreted, other than that inferior and subordinate beings may in fact be destroyed? Furthermore, and of great importance, is the statement that the "inferior ranks of creatures" (a debatable statement in itself) are made for our use. Anyone claiming that God does not pull the strings during several vital stages of the play that is Locke's philosophy has to make new and rationalistic arguments that supports such harsh statements on beings that aren't humans. Even if this is possible, establishing that Locke really reasoned in the same way, but only pretended to use God as his reason, will be a tall order.

Locke is adamant that it is our obvious right to kill dangerous animals like wolfs, lions and tigers (Locke 1969:126,129,209). Why? Because with these animals "men can have no society nor security" (Locke 1969:126,209). This is established as Locke uses these animals as an analogy to people not willing to obey the laws of society; they may also be slain and 
destroyed, as "the safety of the innocent is to be preferred" (Locke 1969:126,129).

\subsubsection{Human and beast}

Returning to reason, it is obvious that Locke sees this as the singularly most important feature of human beings - the defining feature:

Thus far can the busy mind of man carry him to a brutality below the level of beasts when he quits his reason, which places him almost equal to angels (Locke 1969:44).

Without reason we can be "below" beasts, and with it we are close to angels. Furthermore, reason is our "star and compass", which steers us the right way when our fancies and passions attempt to run amok (Locke 1969:44). In Human Understanding Locke names understanding as the defining feature, but the substantive difference between these two terms seems not to significantly disrupt Locke's argument (Locke 1997:55).

If we remove God, and him creating us in his image and so on, from the equation, is there a categorical difference between people and beasts, or only one of degrees?

Locke imagines an oyster, and concludes (based purely on him imagining that it is so) that "it has not so many, nor so quick senses, as a man, or several other animals" (Locke 1997:146). One reason for him thinking that this is so, is that it would be quite frustrating for an oyster to have the mental life of a person, when it is placed by chance somewhere and subsequently bound to that place (Locke 1997:146). This is another kind of Lockean argument that presumes the good design of God, and we can of course hope (but hardly know) that oysters aren't depressed their whole lives because want to, but can't, move.

An interesting twist comes when Locke compares the oyster to a person "in whom decrepit old age has blotted out the memory of his past knowledge, and clearly wiped out the ideas his mind was formerly stored with; and has, by destroying his sight, hearing, and smell quite, and his taste to a great degree, stopped up almost all the passages for new ones to enter; or, if there be some of the inlets yet half open, the impressions made are scarce perceived, or not at all retained" (Locke 1997:146). Whether this person is above the condition of an oyster Locke leaves unanswered, indicating that the difference between humans and beasts is one of degree, not kind.

Locke says that beasts have memories, and can recall them, but that he assumes them unable to compare ideas, reason abstractly or compound ideas into complex ideas (Locke 1997:151,154-6). This is thus the third defining feature of humans proposed by Locke. He states that animals are more than mere machines, and that we "cannot deny them to have some reason"; at this point in Human Understanding he claims that abstraction is the "proper difference wherein they [humans and beasts] are wholly separated" (Locke 1997:156).

As far as overlap between the more intelligent members of the animal community and people of lesser intellect, Locke acknowledges this overlap with the statement that humans who quits reason are below beasts (Locke 1969:44). This is, however, also of less importance for Locke than for some other philosophers, as even the stupidest person is a special part of God's creation, by virtue of belonging to the most noble species. Locke's dualism is thus not rationally established by Locke, but is a result of his theology.

Locke is at times portrayed a member of a "humanitarian movement", which partly concerned itself with animal welfare (Attfield 2011). Attfield (2011) labels Locke a "Christian moralist", and states that he was a materialist that used the status of animals to argue against dualism (Cartesian dualism, not the dualism of Meyer (2001) previously 
discussed). Such a position is, however, hard to establish when one includes Locke's writings on theology. It is, however, important to note that Locke did not postulate that we have an immaterial soul which distinguishes us from animals, but he did argue that God could "add to matter the power of thought" (Attfield 2011).

\subsubsection{Property and nature}

God gave the world to people - in common. This caused a problem, as we can't easily put the world to productive use without individually appropriating parts of it (Locke 1969:134). This is the foundation of Locke's theory of property. How much of the earth did he give us? Collectively: all. Individually: enough "[t]o enjoy" (Locke 1969:136). These rights to property are largely pre-political natural rights, as they relate to man in a natural state (Vanderheiden 2008; Sagoff 2007). A full discussion of whether, and how, these rights translate into the life in political society, is beyond the scope of this article and I refer to Musie (2019) for a recent detailed examination of the broader political implications of the philosophical and religious aspects examined here.

Appropriation of nature is fine for fruits, berries and other things that can easily be separated from the rest of nature, some may say, but Locke states that it also applies to land itself. As long as someone "tills, plants, improves, cultivates, and can use the product of" some piece of land, that land is his - "he by his labour does, as it were, enclose it from the common" (Locke 1969:136). Furthermore, Baird Callicott (2003) names Locke the "theologian of cattlepersons", as his theory of private property even extends to privately owned "animal units".

What then, of wilderness? What of the preservation of "untouched nature" as deep ecologists and other environmentalists goes on about? This part of nature serves as a habitat for both "charismatic" and downright revolting life forms, and is by most modern ecologists considered quite important for the preservation of biological diversity, and the provision of various other ecoservices. To Locke, this is quite simple: land left to nature is waste - "and we shall find the benefit of it amount to little more than nothing" (Locke 1969:142). In fact, "ninety-nine hundredths" of the value of land is attributable to human labour (Locke 1969).

What determines value, then? The compound labour of people, while "nature and the earth furnished only the almost worthless materials as in themselves" (Locke 1969:142). This is a widely held belief, also today, and Rolston III (2020) and Sagoff (2007) argue that this view descends from Locke. Barry (2007) also argues that Locke was the first theorist to "rationally justify" an instrumental approach to both the possession and valuation of nature. Individual appropriation of goods is central to Locke's philosophy, and Plumwood (2006) points out that his approach ignores that all goods are essentially joint products of human and non-human agents (including land).

Another problem related to Locke's theory of property is that it requires an abundance of unclaimed land and goods, perhaps because Locke himself lived in a time where "ecological abundance" was assumed (Ophuls, 1977). Without abundance, problems of distributive justice quickly arise, as goods can no longer be claimed from nature, but must be redistributed if new people, or people previously without property, are to have any. In addition to this, however, he did provide a second Lockean proviso which states that individuals can only appropriate goods insofar as there is "enough, and as good", left for others (Locke, 1969; Liebell 2011). I return to this proviso in the discussion of sustainability and scientific conservationism. The political implications of these considerations have been discussed by various authors, and Musie (2019) provides an account of how this, combined, constitutes an environmental turn in Locke scholarship. I focus only on a subset of the issues 
which are examined in this environmental turn, and in particular the problematic relation between the religious and the rational Locke.

\subsection{Locke, the rationalist Christian}

Despite Locke's rather disparaging comments on nature and its beasts, Woolhouse states that " $t \mathrm{t}$ he picture of man as part of, not set aside from the rest of, nature derives from Locke ..." (Woolhouse 1997:xxiii). Woolhouse admits that Hobbes preceded Locke in this regard, but then seems to argue that Locke was in some way more "fair" to nature, treating "man as a subject for unbiased objective investigation as suitable as anything else" (Woolhouse 1997:xxiii). While Locke acknowledges that beasts have some reason, that stupid people are "below" animals, his dependence on Scripture forces him to regard humans as special, even if his own arguments at times suggests otherwise. Locke's writings also suggest that we have few, if any, obligations towards animals, which we can use for more noble things than just letting them flourish. Also, nature untouched is close to worthless, and is given value solely by the industry of people. According to Baird Callicott \& Frodeman (2009), this view of nature, combined with Locke's theology, provided the "theological warrant to colonial expropriation of native lands". Settlers followed God's instructions to till the land, while the natives did not, as they left nature "wild and disordered" (in the eyes of those with views akin to Locke's) (Baird Callicott \& Frodeman, 2009).

While Locke the rationalist may at times attempt to treat people objectively, he is thoroughly steamrolled by Locke the believer, who places humans at the top of God's hierarchy of created things. The earth was created by God and given by God to people for their use.

\section{LOCKE, ENVIRONMENTALISM AND ENVIRONMENTAL ETHICS}

So how do Locke's thoughts on humans and nature correspond to modern terminology on the subject? Environmentalism is a term often used, but not equally often understood. We will first see how Ramachandra Guha (2014) uses the term in Environmentalism: A Global History, in order to see if Locke can fit into any modern conception of the term. We will then see if a translation of Locke's philosophy to the terminology of environmental ethics can provide further insight.

\subsection{Environmentalism}

Guha proposes three "generic modes" of environmentalism: back-to-the-land, scientific conservationism and the wilderness idea (Guha 2014). In addition to these three modes of environmentalism, there are other important conceptions of our relation to nature that is by Guha labelled "radical", and the more radical ideas are partially covered under the part about environmental ethics (Guha 2014:117). Locke wrote of humans and nature, but this was rarely his focus, and his dealings with the topic can hardly be understood as complete or satisfactory from a modern viewpoint. Connecting his thinking to more developed modern understandings of the subject matter may help us to extrapolate and imagine what sort of ideas are compatible with Locke's political philosophy.

\subsubsection{Back-to-the-land}

Guha's first mode of environmentalism is the "moral and cultural critique of the 
Industrial Revolution", labelled back-to-the-land-environmentalism (Guha 2014:8). There is a romantic longing for the days of yore, and Guha mentions Blake, Wordsworth, Dickens, Engels and Gandhi as some of the more prominent figures (Guha 2014:8). This tradition is most closely associated with Britain, which was the first country to experience full-fledged industrialisation and urbanisation (Guha 2014:14-5). Industrialisation involved the move away from the masses of the people living directly off the land to people gathering in lessthan-idyllic circumstances in the early industrialising cities. While long hours of work were nothing new in agricultural societies, the dismal surroundings in the cities of early industrialisation provoked a longing for nature. Guha calls the longing "romantic", indicating that what is longed for is perhaps not a real past, but some fantasy about an idyllic life in pact with nature (Guha 2014). The realism of their dreams being left for others to ascertain, there was nevertheless a longing for fresh air and green countryside. The longing was not purely health-based or aesthetic, as Wordsworth for example defended the "organic union" between humans and nature (Guha 2014:16). Enclosure of commons, factories and cities proliferating and growing, and nature being "desacralized", was seen as detrimental to humans (Guha 2014:18-9).

This is not a mode of environmentalism that can reasonably be attributed to Locke. We have seen that Locke applauded the appropriation of land, the productivity of human industry, and the transformation of untouched nature - waste - to productive resources. Nature, while being God's creation, is not sacred in the sense that it must be left as it was created, in Locke's view. God created, then commanded us to apply our industry to make use of it - to transform it. Neither does there seem to be any idea that each person must live directly off the land, or in a situation where nature is experienced in a particular form, in order to be healthy, happy or thriving. On the contrary, Locke seems to envision the industrious person that transforms nature as one living in accordance with the intentions of his maker, something one can assume is right, and delightful.

\subsubsection{Scientific conservationism}

A candidate more likely to be compatible with Locke's philosophy is scientific conservation. This tradition is, as opposed to the previous, not attempting to move back from industrial society, but instead to seek better management of industrialisation and the use of resources (Guha 2014:8). Whereas the previous mode was "romantic", this mode aims at being scientific. How can we industrialise without running out of resources, without producing dangerous pollutants; how much timber can we cut and still have some left for the years to come? Sustainability is a term closely connected with this tradition, and finding the sustainable yield of both fish, lumber, water and other resources is a key aim (Guha 2014:8).

The faith in science and human rationality was great at the beginning of the $20^{\text {th }}$ century, and some parallels to James C. Scott's concept of high modernism are applicable to the more ambitious parts of this approach to human-nature relations (Scott 1998). While many exercise extreme caution in their assessment of our understanding of complex ecological systems, others have more faith, and this was "an ideology of 'doom and resurrection,' predicting that agricultural and industrial expansion would destroy the environment unless replaced, forthwith, by more rational and far-seeing forms of resource use" (Guha 2014:39). Instead of scaling back the industrial development, it would have to be guided by more science. In the opinion of Gifford Pinchot, founder of the United States Forest Service, the government was the proper vessel for taking care of the long-term evaluations needed, as "Men die but the Government lives on. The forests, like the race, must live on also" (Guha 2014:39). 
Prevention of waste and "wise use" are central concepts, and some employ a utilitarian definition of what conservation is: "the greatest good of the greatest number for the longest time" (Guha 2014:40). Scientific conservationism, then, could be understood as utilitarianism for the long term. One of the main proponents of the tradition, George Perkins Marsh, explained the need for conservation in terms that does not seem foreign if imagined as the extension of the Lockean philosophy we have thus far expounded:

Man has too long forgotten that the earth was given him for usufruct alone, not for consumption, still less for profligate waste ... The earth is fast becoming an unfit home for its noblest inhabitant, and another era of equal human crime and human improvidence ... would reduce it to such a condition of impoverished productiveness, of shattered surface, of climatic excess, as to threaten the deprivation, barbarism, and perhaps even extinction of the species (Marsh 2002:170-3)

Here we find the argument for "environmentalism as self-interest", an approach evaluated and described more extensively in (Sætra 2014). Marsh's version, however, is more compatible with Locke's philosophy, as it stays true to the story of God being the creator and giver of the earth to humans, something not present in Hobbes's philosophy.

Bassani (2004) argues that Locke's proviso that people can only appropriate goods if this does not lead to deterioration in the situation of others leads to an inter-generational ethic. Such an ethic is not based on a high valuation of nature in itself, but on the needs of later generations, and scientific conservationism is an approach that allows us to use resources in a manner compatible with the Lockean proviso. This is related to the Lockean standard of Kavka, which consists in applying the Lockean proviso across generations (Attfield 2011; Kavka 1978).

In addition, Trachtenberg (2014) also argues that Locke's political philosophy is fundamentally long-term. The idea that people have a right to the produce of nature but not the natural productive processes themselves, and that the government can regulate resource use in order to secure the longevity of the state, lends support to a Lockean notion of sustainability (Trachtenberg 2014). Dobson (1998) also build on Locke's theory of property and his proviso of "enough and as good" as a basis for human restraint regarding resource use. Wissenburg (2013) relays various criticisms of Locke's proviso, as he pursues other paths, and philosophers, towards green liberalism. One point of criticism is that Locke's proviso says little about distributive justice, but Vanderheiden (2008) suggests that the Lockean proviso does entail a consideration of distributive justice.

\subsubsection{Wilderness idea}

The final major mode of environmentalism Guha mentions is the wilderness idea. He calls this tradition a combination of "elements of morality, science, and aesthetics" (Guha 2014:8). This mode is also seen as a sort of reaction to the environmental degradation that follows from industrialisation and the general growth and spread of the western civilisation; while seemingly similar to back-to-the-land, the proponents of this tradition do not seek that pastoral life, but focuses on preserving wild nature - locking up and protecting the pristine and still untouched parts of the natural world (Guha 2014:8).

While this form of environmentalism has been influential, it is not the most promising form of environmentalism for anyone seeking something compatible with Locke's philosophy. Nature untouched is as we remember waste in the eyes of Locke. The champions of this tradition, such as John Muir and the Sierra Club, have achieved a lot in terms of preserving areas from human incursions, in particular from industrial use and commercial development. However, this mode of environmentalism is not Locke's 
environmentalism, and will thus not be considered in more detail here. Locke seems to believe that nature was given to us for us to use, not simply to contemplate; In any respect, anyone categorising untouched nature as waste cannot be imagined to belong to the same category as Muir and his likes.

\subsection{Environmental ethics}

Let us now see how Locke may be portrayed in the terminology of environmental ethics. Environmental ethics is sometimes perceived as the "attempt to expand moral thinking and action in two directions: beyond the human species and into the distant future" (Nolt 2015:xii). While the discipline can often be perceived as "activist", I will deal with environmental ethics as the analysis of the expansion of our moral communities. How far does Locke imagine that man's moral community extends, towards both non-humans and the distant future?

A moral community consists of all entities classified as morally considerable. An entity that is morally considerable is an entity whose welfare or interests are considered to be of ethical value. These considerables are also called moral patients. We may include entities that do not have reason, consciousness, "morality," a soul, etc. etc. as citizens of our moral community. Whether such entities are oysters, the senile, rivers, new-borns, trees, the intellectually challenged, or whatever else, matters little here - everything can potentially be a part of a moral community. Not all of these can be assumed to act ethically, however. While all members of the community are morally considerable, the "passive" members receiving ethical consideration are moral patients, while those expected to have the competence required to act ethically are moral agents (Nolt 2015:47).

This framework lets us differentiate the various forms of morality in different societies; from the narrow moral communities of an imagined tribe where only fellow tribesmen may be of ethical interest (anyone else being fair game) to the deep ecology of Arne Næss where practically everything is morally considerable, while only humans are considered moral agents (Næss 1989:23).

\subsubsection{Anthropocentrism}

The ethical theories that focus on human beings in particular are often referred to as anthropocentric (Nolt 2015:64-5). Locke, says Trachtenberg (2014), is "unabashedly anthropocentric", and this aspect of Locke's philosophy has become evident in this article.

Nolt (2015:63) credits monotheism with the shift from ethics being contained in each culture or society towards the development of a broader human ethic, which in due course gave rise to such phenomenon as human rights etc. In the continuation of his discussion of monotheism, he describes a view that sounds very familiar after our examination of Locke's philosophy:

[W]ith the rise of monotheism in late antiquity, Western philosophy came to see

the world as an exquisitely designed hierarchical structure in which all things had God-given values and purposes. Inanimate substances, like water and air, existed to serve the needs of plants, animals and humans. Plants served as good for animals and as food and clothing for humans. Animals served as good for other animals and, again, as food and clothing for humans (Nolt 2015:64).

Humans on top, and the rest as resources, can thus serve as our starting point in understanding anthropocentrism (Nolt 2015:64). Axiological anthropocentrism is the conception that value is "assigned to things only by and for human purposes", a view distinct from the religious view that God, or God's purposes, is the source of all value 
(Nolt 2015:64). In the discussion of Locke, we have seen that it is sometimes difficult to determine if things are good because they serve human interests, or if the serving of human interests is only good because that again implies that God's interests are being served. My claim is that Locke equates God's and man's interest to such a strong degree that we may consider his philosophy anthropocentric, even if his anthropocentrism may be based in theology and the desire to satisfy God's interests.

Axiological anthropocentrism is often conflated with ethical anthropocentrism, Nolt claims, which is "the view that only humans ... are morally considerable" (Nolt 2015:65). The strict version states that only humans matter, while somewhat milder forms may allow some (but not much) value to certain non-humans (Nolt 2015:65). Axiological anthropocentrism may allow great ethical value to non-humans if humans benefit from them, or simply value them, while ethical anthropocentrism is more focused on human selfinterest.

\subsubsection{The short or the long term?}

The final question is whether Locke's anthropocentrism is short-term or long-term (Nolt 2015:65). While near-term anthropocentrism indicates that our moral concern is limited to human beings "whose life spans overlap ours", the long-term version raises our moral view, so that we also include future people - "some decades, centuries or even millennia later" (Nolt 2015:65). Nolt states that the near-term variant is the "dominant ethical perspective of contemporary public life"; so dominant is this view, he states, that even those with longer perspectives are forced to state their views in the frame of the nearterm in order to be taken seriously (Nolt 2015:65).

\subsection{Locke, scientific conservationism and anthropocentrism}

To summarise this part, we have seen that Locke can hardly be called an environmentalist in the back-to-the-land or wilderness idea tradition. While there are obvious challenges associated with placing a thinker from the 17th century in any modern category like this, we did see that what Guha labelled scientific conservationism might be compatible with parts of Locke's philosophy. Due to the limited amount of work done on questions regarding nature by Locke himself, any such categorisation involves an extrapolation of his philosophy into areas unknown in his own day and age, and we must be careful not to confuse this extrapolation with what Locke actually wrote. I label my approach in these respects "Lockean", in order to imply that there is a likeness to the basic philosophy of Locke, without making any claims of authenticity.

Locke places humans at the centre of attention, partly by way of the fact that God created us and gave us the earth and nature for our "support and comfort" (Locke 1969:123,134). Another aspect of his anthropocentrism is his political framework where people by consent and contract establish rights and legitimate authority (regarding all, not just human affairs) (Locke 1969:169). Locke's anthropocentrism is ethical anthropocentrism, where animals seem to have some value (can't be killed for fun), but far less than the value of human beings (which can put animals etc. to better uses than letting them live).

Are there reasons to believe that Locke's perspective is longer than what Nolt says dominates the current political debate, then? Locke's individualism causes problems also for scientific conservation, with its emphasis on individual self-interest and short-term interests as the main problems, and the state as the guarantor of long-term benefits as the solution. Such an individualistic reading of Locke's political philosophy is criticised by Musie (2019), as he suggests a Lockean philosophy that is relational, but a thorough examination of these 
issues is beyond the scope of this article,

Locke did lament the human inclination to choose the lesser, but more immediate, good when given such choices, but his political framework leaves very little room for overruling the short-term choices made (Locke 1997:251). The state may intervene, but primarily to prevent the short-term effects to property (including life) caused by insecurity in a natural state (Locke 1969:184-5, Locke 1997:78-9, 80).

Locke's statement that people seek to care for their young does not seem to translate into the idea that future generations should be the focus of public policy. Furthermore, the intuitive interpretations of Christianity as a factor leading to the preservation of creation and a desire for securing the flourishing of humanity for generations finds little support in Locke's political theory. There is little support for a forced long-term perspective not desired by the people in Locke's political philosophy. Locke does mention "prerogative", but limits its scope to dealing with "accidents and necessities" caused by the laws not being detailed enough to prescribe for every imaginable situation (Locke 1969:204). The purpose of the government is to preserve the "peace, safety, and public good of the people", and any "environmentalist impetus" would thus have to be understood as public good (for the current generation) or in accordance with the will of God, which Locke values (Locke 1969:186).

\section{CONCLUSION - THE LIMITS OF LOCKEAN ENVIRONMENTALISM}

Locke gave the pioneer impetus and inspiration to rationalism, to environmentalism, and to the search for a social science (Cook 1969:xxxii).

Having examined the fundamentals of John Locke's philosophy, and his philosophy of nature in particular, we have seen that Locke is a philosopher of several hues, if not several distinct colours. Starting with the quote above, we immediately see that we have questioned both the rationalism and environmentalism mentioned by Cook. The implications of these findings provide the impetus for a broader evaluation of the consequences of a Lockean political approach to nature.

Locke in certain ways separates humanity from the rest of nature. Humans are above the rest, as we are the preferred species granted special privileges by God himself. While he sometimes sounds like a rationalist, I have argued that rationality is of limited importance in Locke's theory, apart from playing a supporting role for Scripture. The laws of nature, the laws Hobbes used as rationally derived rules for peace, are for Locke "the will of God" (Locke 1969:190). Locke sets us apart from nature and makes us special. However, there is a positive side this his anthropocentrism as well: Locke sees us as caretakers, whose privileged position also entails some responsibility. He also states that the fundamental law of nature - the fundamental will of God - is the "preservation of mankind" (Locke 1969:190). It is hard to sound more anthropocentric than this, but could also argue that the preservation of mankind requires the preservation of mankind's habitat. We are far away from the biospherical egalitarianism of deep ecology, but perhaps some other form of environmentalism can result from the religious philosophy of Locke (Næss 1989).

Locke could be understood as providing the foundation of a form of environmentalism based on stewardship (Trachtenberg 2014). The best parts of Locke's Christianity, from an environmentalist viewpoint, are the ones where he uses Scripture to limit the rights to destroy other beings and nature. Proper usage and non-waste are important aspects for Locke, but, alas, for anyone not willing to take God's word as their authority, individualism and the limitation of the state is what they think of when they hear his name. The 
philosophical and rational parts of Locke's theory and the religious aspects are deeply intertwined, and anyone attempting to purge God from his theory is left with a rather unsatisfying creation that seems to be (and in fact is) incomplete. Keeping God in the picture completes his theory, but the result is highly anthropocentric, and Locke views humanity's relationship with the natural world as highly instrumental. We need the natural world to thrive, so we must preserve it, but we have no obligations to it apart from that. God commanded people to make use of the natural world, and Locke himself views nature which is not put to human use as waste. I have argued that there is a clear path in Locke's philosophy towards a form of environmentalism based on scientific conservationism and sustainability, but that the wilderness idea and back-to-the-land varieties of environmentalism can hardly be supported by relying on Locke's ideas.

\section{BIBLIOGRAFÍA}

Attfield, R. (2011). The ethics of environmental concern. University of Georgia Press.

Baird Callicott, J. \& Frodeman, R. (2009). Encyclopedia of environmental ethics and philosophy. Macmillan reference USA.

Baird Callicott, J. B. (2003). "A critique of and an alternative to the wilderness idea". In A. Light \& H. Rolston III (Eds.) Environmental Ethics. Blackwell Publishing.

Barry, J. (2007). Environment and social theory. New York: Routledge.

Bassani, L. M. (2004). "Life, liberty, and...: Jefferson on property rights". Journal of Libertarian Studies, 18, 31-88.

Cook, T. I. (1969). "Introduction", en J. Locke. Two Treatises of Government. New York: Hafner Publishing Company.

Dowling, A. C. (2001). "Un-Locke-ing a Just Right Environmental Regime: Overcoming the Three Bears of International Environmentalism-Sovereignty, Locke, and Compensation". Wm. \& Mary Envtl. L. \& Pol'y Rev., 26, 891.

Guha, R. (2014). Environmentalism: A global history. Gurgaon: Allen Lane.

Kavka, G. (1978). "The futurity problem”. In R. I. Sikora \& B. M. Barry (Eds.). Obligations to Future Generations. Philadelphia: White Horse Press, pp. 186-203.

Liebell, S. P. (2011). "The Text and Context of "Enough and as Good": John Locke as the Foundation of an Environmental Liberalism". Polity, 43(2): 210-241. DOI: 10.1057/pol.2010.28

Locke, J. ([1689]1969). Two Treatises of Government. New York: Hafner Publishing Company.

Locke, J. ([1690]1997). An Essay Concerning Human Understanding. London: Penguin Books.

Marsh, G. P. (2002). "Man and nature”. Organization \& environment. 15(2): 164.

Meyer, J. (2001). Political Nature. Cambridge: MIT Press.

Mousie, J. (2019). "The Environmental Turn in Locke Scholarship." Ethics and the Environment, 24(1): 77-107, DOI: 10.2979/ethicsenviro.24.1.04

Nolt, J. (2015). Environmental Ethics for the Long Term. New York: Routledge.

Næss, A. (1989). Ecology, community and lifestyle. Cambridge: Cambridge University Press.

Ophuls, W. (1977). Ecology and the Politics of Scarcity. WH Freeman.

Plumwood, V. (2006). "Feminism". In A. Dobson \& R. Eckersley (Eds.) Political theory and the ecological challenge. Cambridge: Cambridge University Press.

Rolston III, H. (2020). A new environmental ethics: the next millennium for life on earth. New York: Routledge.

Russell, B. (2009). The Basic Writings of Bertrand Russell. Oxon: Routledge Classics.

Sagoff, M. (2007). The economy of the earth: philosophy, law, and the environment. Cambridge: Cambridge University Press.

Scott, J. C. (1998). Seeing Like a State: How Certain Schemes to Improve the Human Condition Have Failed. New Haven: Yale University Press.

Stephens, P. H. (2016). "Environmental political theory and the liberal tradition". The Oxford 
handbook of environmental political theory. Oxford University Press.

Sætra, H. (2014). "The state of no nature: Thomas Hobbes and the natural world". Ecology \& Safety 8 , $177-193$.

Thomas, K. (1991). Man and the natural world: Changing attitudes in England 1500-1800. UK: Penguin.

Trachtenberg, Z. (2015). "John Locke: 'This Habitable Earth of Ours"”, en P. F. Cannavò \& J. H. Lane Jr. (Eds.) Engaging Nature: Environmentalism and the Political Theory Cannon. Cambridge: MIT Press, pp. 99-116. DOI:10.7551/mitpress/9780262028059.003.0006

Vanderheiden, S. (2008). Political theory and global climate change. Cambridge: MIT press.

White Jr, L. (1967). "The historical roots of our ecologic crisis". Science 155(3767): 1203-1207.

Wilson, H. (2016). "Environmental political theory and the history of Western political theory". In The Oxford Handbook of Environmental Political Theory. Oxford: Oxford University Press, pp. 19-33.

Wissenburg, M. (2013). Green liberalism: the free and the green society. New York: Routledge.

Woolhouse, R. (1997). "An Essay Concerning Human Understanding”, Chapter Introduction, en J. Locke. An Essay Concerning Human Understanding. London: Penguin Books, pp. ix-xxv.

Zagorin, P. (2009). Hobbes and the Law of Nature. Princeton, NJ: Princeton University Press.

\section{Breve currículo:}

\section{Henrik Skaug Sætra}

Assistant professor in Political Science at Østfold University College. His research interests are centered around the search for robust and minimalist justifications of the state, and he has thus focused particularly on Thomas Hobbes and the other classical social contract theorists. Besides classical political theory, he is interested in environmental ethics and the effects of technology on individuals and society. 